\title{
The problem of old age in the context of family caring responsibilities
}

\section{Problem starości $w$ aspekcie zadań opiekuńczych rodziny}

\author{
Grażyna Kowalik \\ Department of Nursing Skills and Labor, Institute of Nursing and Midwifery, Faculty of Health Sciences, Jan Kochanowski University, \\ Kielce, Poland \\ Head of Department: Prof. Bogdan Chazan MD, PhD
}

Studia Medyczne 2014; 30 (1): 61-68

Key words: old age, care, family.

Słowa kluczowe: starość, opieka, rodzina.

\begin{abstract}
Recent years show that demographic changes are leading to lengthening of life expectancy, to the extension of old age and consequently to a growing number of elderly people. Research indicates that by the mid-twenty-first century the number of elderly people will increase to 370 million. The constantly growing number of older people means that care of this group of patients acquires a new meaning, especially because most of them will wish to remain under the care of the family. This fact entails the need to involve family members to assist in the care of an elderly person in the home and beyond. Family potential understood as the ability to care for the old and sick has systematically decreased in recent years in Poland. The tendency of Poles to travel abroad for work purposes, especially for women, is one of the highest in the OECD. Migration of family members means that support for an older person may take various forms. Australia, the United Kingdom, and the United States recognized that the scope of proper care must include the involvement of all stakeholders in compliance with the Bill of Rights and Duties of a nursing home boarder and the Standards and Elderly Care regulations issued by the Australian Government. In the Polish Act on social assistance in 2004, there is no clearly defined notation associated with the provision of care because of old age and loneliness. Controversial is the fact that the Chinese authorities have decided to punish family members for not visiting old people.
\end{abstract}

\section{Streszczenie}

W ostatnich latach zwraca się uwagę na zmiany demograficzne prowadzące do stałego wzrastania średniej długości życia, a tym samym do przedłużania się okresu starości i w konsekwencji do zwiększającej się liczby osób w podeszłym wieku. Badania wskazują, że liczba ludzi starszych w połowie XXI wieku wzrośnie do 370 milionów. Powoduje to, że opieka nad tą grupa pacjentów nabiera nowego znaczenia, zwłaszcza że większość z nich pragnie pozostawać pod opieką rodziny. To sprawia, że członkowie rodziny zaangażowani są w opiekę nad starszą osobą w środowisku domowym i poza nim. Potencjał rodziny rozumiany jako zdolność do świadczenia opieki starym, chorym osobom w ostatnich latach w Polsce systematycznie się zmniejsza. Skłonność Polaków do zagranicznych migracji zarobkowych, szczególnie kobiet, jest jedną z najwyższych w krajach OECD. Migracja członków rodzin spowodowała, że wsparcie dla starszej osoby może mieć różne formy. Zarówno w Australii, Wielkiej Brytanii, jak i Stanach Zjednoczonych przyjmuje się, że w zakres właściwej opieki musi wchodzić zaangażowanie wszystkich zainteresowanych stron. Taki pogląd zawarty jest w Karcie praw i obowiązków mieszkańca domu opieki oraz w Standardach opieki nad osobami starszymi wydanych przez australijski rząd. W polskiej ustawie o pomocy społecznej z 2004 r. nie istnieje precyzyjny zapis związany z zapewnieniem opieki ze względu na starość i samotność. Kontrowersyjny jest fakt, że władze Chin postanowiły karać członków rodzin za nieodwiedzanie starych ludzi.

\section{Introduction}

Older age is a sign of the passage of time. Currently the number of older people is growing. Currently, there is a decrease in the number of births. Eurostat figures show that $13.5 \%$ of Polish citizens have currently reached or exceeded 65 years old $[1,2]$. Scientists seeking to extend the life of people achieve more and more success and have already delayed the death of flies and mice. There are signs that in the future one may even survive two centuries [3].

Many comorbidities of seniors contribute significantly to the reduction of physical activity of this group of people. Older people deprived of human contact, rejected by the family and relatives, close in on themselves. Such behaviors cause older people to stop fighting for survival and consequently give up. That is why, in this group of older people there is the 
highest percentage of suicides. The greatest number of people who commit suicide is in the United States (accounting for 19\% of suicides). Others are limited to watching TV, going to church and the doctor [4].

Older persons should have a sense of usefulness and belonging. They must reside in the current family and social life, and not be on the sidelines. Therefore, according to the statement of the Japanese philosopher Daisaku Ikeda, old people need to be given a reason to continue living [4]. One of the major challenges of modern developed societies is to provide care to the elderly [5].

It is believed that the role of the family, due to conditions rooted in our cultural model of family in relation to the exercise of care measures, should be more and more significant.

\section{The most common problems of elderly people}

Old age is an inevi and natural destiny of every living being. It is a part of life, and therefore it should be understood as a factor of growth and development. Man, in contrast to animals, feels and knows that he is getting old. Depending on how a person looks at his old age, he feels it, preparing for it and he may change it [6]. Ageing is a process in which the biological activity decreases with increasing age of the organism.

As a result of the aging process, progressive irreversible changes occur in man, in his psychomotor ability, problem-solving capabilities, memory, motivation and emotion. According to the WHO classification old age can be divided into three sub-periods: 60-75 years old, 75-90 years old, and over 90 years old [7].

Old age is one of the most important factors determining the scale of the needs of public health care and social assistance. The most important problems of the elderly can include illness, loneliness, disability, living in poverty, and a sense of worthlessness. Characteristic for the elderly is the coexistence of a variety of conditions, which often leads to excessive pharmacotherapy. Treatment of patients without inspecting the health status leads to a series of consequences and complications - iatrogenic drug-induced syndrome. For the geriatric big problems in contemporary gerontology are recognized disorder or the physical and mental diseases. The most commonly occurring disorders (diseases) occurring in the elderly include falls and impaired mobility, urinary and fecal incontinence, visual and hearing impairment, dementia and senile depression [8].

These phenomena are quite common and are often neglected (left without diagnosis and intervention). Because of their excessive length, and multiple causality, they cause difficulties in the treatment of progressive loss of independence of older people and influence the lower quality of life of seniors by reduc- ing their daily activities, mobility, and contact with other people and the environment [9].

Research points to existence among the elderly of depression and suicide, which may be a consequence of the failure to prepare for this period of life and lack of acceptance of old age, as a natural stage of the human life cycle [10].

Quality of life depends on the old person's psychological and biological reserves that allow the mobilization of mechanisms of adaptation and defense and to take compensatory measures. There is often a tendency to hypochondria and clearly visible self-centeredness, which increases the need for approval. According to the survey, in early old age health problems predominate, while later there are welfare problems [11].

Problems that affect many older people are:

- Difficulties of the financial situation, motion sickness, daily household duties.

- Difficulties relating to the progress of civilization and technical developments that require the acquisition of new skills (mobile phone, computer, use of an ATM).

- Relationships with family or other people expressing a lack of mutual understanding and proper place in the family system.

- The need to change the place of residence due to the financial conditions (high rent) and architectural barriers (no elevator).

- A negative balance of own life and associated with it negative self-esteem, lack of acceptance of their own destiny and a sense of loneliness.

- Decrease in physical and mental efficiency [12].

It is believed that it is possible to maintain the body in perfect condition until death. The term successful aging is the optimal course of aging, which is characterized by the absence of disease, positive health behaviors (active lifestyle, proper diet) and minimal physiological, psychological and social deficits, assigned to the calendar age.

Successful aging is observed in only about $10-15 \%$ of the population; the rest age normally, experiencing the typical age of organ dysfunction, most often pathological, due to concomitant diseases. A relationship between various factors and aging is observed. Among the factors are education, financial situation, staying married, keeping fit, positive self-care, maintaining proper weight loss and dietary recommendations [13].

It can be assumed that older people improve their well-being if they improve their position in society. On the one hand, it creates social campaigns showing the importance of the elderly, while on the other hand it creates a tendency to discriminate against seniors, the so-called ideology of ageism. This ideology is based on the cult of youth [14].

It is important to remember that age cannot be considered as a crime that requires social marginal- 
ization [10]. An example of a country where old age is accorded deference and respect is Japan [15].

The aging population and the challenges related to health and the welfare system require us to take consistent action that will enable us to provide individual attention and ensure independence of protégés and increase the level of satisfaction with the provided care and support for older people, provide protection for older people, to create the best, most comfor living conditions. A senior efficient person is not a burden to the family or care and treatment, but may be someone important in the life of the community [16].

\section{Care of the older person - a challenge for family members}

According to research, care of the old and dependent persons in Poland is still provided by the family, which in modern society is the main source of care $[17,18]$. It is known that there is a change in the function and structure of the family.

As a result of many social, economic and cultural factors many multigenerational families disappeared in which older people could count on care and interest. There are so-called "nuclear families" with only one or two children. These families have a greater degree of focus on maintaining a household with their own goals and aspirations. The seniors want to be among family and live together with them the joy and care. An old person is related to their home; it feels good and safe. Society should understand the characteristic behavior for the elderly: dislike, distrust or inability of the old person to adapt to the new environment.

Family can be regarded as a system of repayable assistance. The important role of the family in relation to older people should be emphasized. It is revealed especially in elderly disease. The most important are emotional bonds between all family members.

There is the story of an 87-year-old single Italian who volunteered for adoption. He was looking through a newspaper advertisement for a family with whom he could live. He received many proposals. He chose the one that was signed by all members of the family. The new home has been taken care of [19].

Care for the elderly is the ratio between the two entities and it is associated with responding to the needs and capabilities of the other person. The concept of care for the elderly is associated with a daily life that is personal care (bathing, dressing, feeding, assistance with mobility). It should be remember about the necessary activities for the proper functioning of not fully independent people (paying bills, shopping, cleaning, cooking). Care is also helpful especially for people with dementia $[20,21]$. It is important to communicate and interact with them.

An important social aspect of care is simply to accompany an elderly person in their daily life. It is necessary to support seniors due to normative and moral responsibilities. Types of support are not established, but tend to be developed and negotiated. This process also provides emotional support $[22,23]$. Care should be exercised according to the specific virtues of caring that are necessary so as to best accomplish the objectives of care [24].

One of the virtues of caring is mindfulness (moral perception). It is defined as being sensitive to the problems that require a specific moral reaction when a caring person notices that a person is in need and responds appropriately. Mindfulness combines empathy with the ability to anticipate the needs of the other person.

Another virtue of caring is communicative sensitivity, which means engaging speakers, aimed at identification of needs and/or observing the reaction. It is important to assess whether the requirements have been met. This action may be verbalized or not [20, 25].

One of the most important virtues of care is respect, which has much to do with satisfying the needs of other people. In this case, the respect is associated with the belief that others are worthy of attention and sensitivity to the person who provides care and that they are able to understand and express their needs, as they are not worse than the caregivers only because they cannot meet those needs. They should respect the wards treating them in such a way as not to deprive them of dignity in the eyes of themselves and in the eyes of others and accept their abilities [20, 25]. Care for older family members is both physical and emotional - a challenge that not everyone can or wants to face. However, the reality is changing and putting an elderly person in a professional care home is becoming normal for the young generation, but for many of the elderly it is still a duty.

There is a belief that family members show greater care and attention than a person performing the functions of caring professionals. Whatever the motivation, however, there is considerable commitment and one must be able to deal with such a situation. Taking such action requires sacrifice, patience, responsibility, peace, good organization and a number of other characteristics and behavior. Taking care of yourself is also justified. A person who does not meet your needs, and does not develop their capabilities in the long term may be unable to provide good care for others, or simply may not want to do it or do it inefficiently. The way we feel towards family members depends on their ability to provide care [20].

When the older person has a foothold in the family, he/she gains strength and ability to work, even even to a small extent, this age can surprise with something new and even a positive experience [26].

It is known that the Chinese parliament has introduced a new law providing for the fact that adult offspring are required to visit their parents. If you do not do it, you may bear criminal responsibility. 
Chinese people are of the opinion that you should visit elderly parents (as often as possible), and if they feel neglected, they may take their children to court. The authorities have decided to follow this path as a result of increasingly appearing reports of elderly people abandoned or ignored by their children. It is true that China does not have a social security pension. This country does not create social policy and does not provide system solutions [27]. As can be seen, the media often depict stories of parents who are abused and neglected. They inform about the children who are trying to take control of the property of aged parents without their knowledge.

In the Polish Act on social assistance in 2004, there is no clearly defined notation associated with the provision of care because of old age and loneliness. Taking into account the income thresholds defined by this law, many of the elderly are "too wealthy" when it comes to the right to benefits [28].

In the Criminal Code section 210, the exposure of life and causing death by abandonment is punishable by up to 8 years in prison. There are cases where a lack of due care by the older person's family members resulted in criminal liability [29]. The law clearly argues for the need to care for the elderly. Children should not be responsible for the care of the elderly because is is the responsibility of state authorities. The pressure of penalty should not be the motive for interest in an aging parent.

\section{Care for the elderly in the light of the migration of family members in Iceland}

Migration of Poles, especially of women, is one of the highest in the OECD countries [30, 31]. Research also indicates that in 2010-2020 as a result of emigration and the aging population, the number of people of working age in Poland will decrease by about $6 \%$ [32].

In Poland, emigration is one strategy for providing social security to members of kinship, according to the theory of family investment. In Iceland Poles represent the largest population of foreigners - in 2010 it was $44 \%$ of the people who live there of foreign nationality. Arrivals of Poles in Iceland are economic in nature [33]. Emigration of an adult child in the Polish conditions may mean that the old parent will feel a lack of support, assistance and care. Poland among the 13 EU countries dominates in terms of the percentage of people who think it is only family that is responsible for the care of the elderly. It is worth noting that the migrants in Iceland bring their parents to the world of the Internet to become more involved in their lives. Older parents, if health permits them, visit their children in Iceland [34].

Research from 2008 shows that migrants negotiate the scope and form of caring for parents. Direct personal assistance in the event of migration is not possi- ble, but there are many other forms of assistance and support that exceed the boundaries of nation states.

The majority of respondents (almost 70\%) help their parents living in Poland [34]. Care for parents of migrants across borders of nation states takes many forms, such as personal assistance, instrumental homework help, assistance in dealing with administrative matters, financial assistance and emotional support.

Direct personal care in a situation of migration is not possible, but there are many other forms of assistance and support that exceed the boundaries of nation states. Noteworthy is financial support (the dominant form of aid). As emphasized by the respondents, this type of support supplements retirement benefits received by parents [34]. A survey carried out in 2010/2011 shows that the financial support of the migrants is offset by support from elderly parents (grandparents) who look after their grandchildren - children of migrants. If parents require care, they apply the division of care responsibilities with their children. Migrants support financially their parents, or siblings, who for a fee takes care of old parents.

Other strategies to support elderly parents include the purchase of household appliances to facilitate life for older people, the purchase of drugs and arranging special treatments, the financing of repairs and the purchase of items such as televisions, computers, clothes, arranging temporary work (usually summer) in Iceland for relatives and people who caring for aged parents sometimes are organized holidays [34].

Interviewes describing the assessment of care and support to parents can be divided into three groups. The first should include those who devote themselves to care, in spite of their difficult financial situation. The second group are people who are involved in the commitment with limited resources and additionally burdened with the care of dependents.

In the third group, it is necessary to identify those statements that demonstrate the absence of real interest in the situation of parents, mostly out of fear that caring for the old parent may lead to job losses [34]. Helping parents living in Poland is in a sense the implementation of both the culture of care, as well as proof of the success of the migration, which should not refer only to the individual migrant people, but, according to the new economic theory of migration associated with the entire household, with a network of relationships [35].

\section{Family support in the care of older people in institutional care}

Socio-economic conditions significantly affect the life of the family, intergenerational relationships, the degree of satisfaction of needs and priorities in life.

The potential of the family depends on the size, structure and socio-economic development. What is 
more, in recent years willingness to care for the old and sick members of the family in Poland has systematically decreased for demographic, economic and social reasons. Contacts in families are less intense, followed by weakening ties.

The number of people obliged and able to provide care for demographic reasons is gradually decreasing and this phenomenon is on the rise [36, 37]. Excessive involvement of women in paid work limits the ability to care for elderly family members. Increasingly, the old person is at a disadvantage in the family. It is claimed that there is an increase in caring responsibilities for the elderly, which would necessitate making the institutions outside the family $[18,36]$.

There are stages of old age that without specialized and full time care are impossible to deal with. Some old people who are all alone in a nursing home feel needed and safe. But there are those who are residing in institutional care who feel lonely, and are not visited by relatives. Specialists say that at the beginning of solitude fades in man the desire to live, and then life itself. An elderly person leaving the family home feels resentful, frustrated, useless, cheated and rejected.

In the literature there are described first contacts of the elderly with their children, as intimacy at a distance. A large number of older people want to be at a distance from their children without being in social isolation from them $[37,38]$. Older people avoid strangers' care because they cannot submit to their arguments and feel overwhelmed by them, especially when several people at the same time are trying to convince them to do something [17]. An important task for the family is the regularity of visits to the facility. Elderly people often do not realize about the true state of their health, which is why the family should take care of their parents, by involving them in an active life. Giving tasks to those people who perform them alone or in association with other persons or family members can contribute to feeling a sense of their usefulness. There are people in old age in whom there resides a hidden talent for music, poetic or otherwise; you just need to awaken it, encourage them to come up with the initiative.

In care institutions there often stay single persons who did not have children, whose families live outside the country, or those who have family ties that are weak or have been severed. This situation requires the substitution of family relations by substitute relationships. This need can be met by providing seniors, for example, contact with different people of a similar or younger age [39].

A well-functioning family care home provides an atmosphere of warmth and friendliness, includes a selected therapeutic and caring team, develops and implements individual plans to support people, a willingness to realize ideas and unlimited support of the family, groups, self-help and volunteerism.

\section{Care for the elderly in Australia}

In Australia and in the United Kingdom and the United States it is recognized that the scope of proper care for the elderly must include the involvement of all stakeholders [40, 41].

In Australia, such a view is contained in two documents. One of them is the Bill of Rights and Duties of a nursing home boarder and the other is the Standards of Care for the Elderly issued by the Department of Health and Human Services in this country [41-43].

These standards specify that the family ward can freely participate in activities for the sense of belonging, privacy and dignity of their own leisure activities and pursue interests. The family should also show emotional support, such as assistance in adapting to life in a nursing home, including overcoming feelings of grief and loss $[44,45]$.

Similarly, the International Nursing staff [46] and the Australian Nursing Council [42] state that the nurses should work with the families of patients by respecting their feelings and beliefs.

It seems that this approach to care of the elderly shows understanding of older people and their problems, including those stemming from the inability of adaptation. In Australia in 2001-2002 research was conducted on the issue of nursing staff perceptions of interaction with the families of nursing home charges [43]. The Australian research shows that many families want to keep in touch not only with their relatives in a nursing home, but also with facility staff as it helps to alleviate feelings of guilt towards the left relative in a nursing home, through extensive participation in the care of their loved ones, people who have a sense of continuity, meaning and validity of their caring role.

The interaction with the families of wards is part of the program of work of nursing homes for the elderly. Australian research results show several key categories, describing the staff contacts with families of patients. These include:

The process of transferring to a nursing home (the need to create programs of teaching aids and adaptation to the new situation, both for residents and their families, collecting accurate information on inmates from family members).

Forming relationships between staff and family (trust for families regularly visiting seniors, pointing to the need for help with feeding, taking residents for walks).

The need to maintain the distance of staff in relation to the family (despite involvement in care), need to appreciate family and senior personnel caring for the ward.

Unaccep behavior (not condoning the behavior of family members especially troublesome for staff such as complaints, excessive demands and special treatment of care) [43]. 
It is known that many nursing homes are still tied to the traditional care model, derived from hospitals. In the model, the interaction with the family is in the background. There is a need for a business model of a nursing home where the family will be involved in all spheres of its activities. It seems that all the care staff should receive training on how to interact with the families of residents and this aspect should be part of the staff appraisal. In health properly understood you cannot interfere, but work in this area.

\section{Care for the elderly, as a process of understanding}

One can think about the practical application of the concept of health understood as a process of understanding in the care of the elderly. This form of care is a unique approach in which the problem is defined only with an objective perspective, but also from the point of view of the person under the care. The nursing process based on mutual understanding through agreement creates a bridge between the importance assigned to interpretation by the person requiring care and the importance assigned to this situation by caregivers. The intention is to understand the process and approval between the people involved. Conditions that must be fulfilled to talk about health as a process of understanding, are understanding and knowledge of different perspectives, states, and psychological situations of the elderly. Understanding is the proper interpretation of the observed behavior and family relationships.

In caring the most essential aspect is to accept the man as he is, to respect his right to dignity, respect, and choice. The understanding should apply to both professionals and caregivers of family members and dependents. One should understand the difficulty and importance of the relationship between the carer and the person needing help $[47,48]$.

It seems that the caretaker should be involved in activities and see them as meaningful. Feeling pleasure of care is possible when the daily, even the most difficult to perform tasks are accompanied by caregivers' positive emotions resulting from a sense of "being good". It is advisable when the work is accompanied by a creative approach to their operations; caring effects are visible when the person in the role of caregiver experiences high emotional and intellectual commitment. It is particularly important that the work supervisor gives a sense of meaning, translated into responsibility towards oneself and others. All seniors should get a chance to change their life for the better, one in which they would still be needed and kindly accepted.

\section{Summary}

Longevity is for man a chance for creative development; it sets challenges to be overcome. Old age is seen as a value, the moral task for the senior and for the younger generation [49]. This stage of life can be a joyful summary of the achievements as well as a safe stage of life of older people that can be useful and serve the general good. This awareness requires a new social and moral climate in relation to the issue of aging and geriatric care. The attitude of young people to older people (understanding, acceptance) must also change [50].

The stages of old age do not take place according to a schedule, but are very diverse. Good condition favors the well-being of an older person and the culture of society, a sound social policy and thoughtful, efficient social assistance programs.

Contemporary family structure is not conducive to the formation of optimal conditions for taking care of elderly, chronically ill and disabled at home [51, 52].

Sending seniors into a facility means handing them over. It is known that language has a powerful impact on behavior and thought. This form of language makes the senior be treated as an object. It usually reflects something unnecessary, and then someone else is responsible for this.

An older person, regardless of age, needs love and support from loved ones. Ensuring the provision of care in old age is associated with responsibility for their actions, interest in health, and the environment in which the person lives entrusted to professional caregivers. It is believed that the family should be a key subject of interest in the education of medical and nursing staff, because, as a fundamental unit of society in a fundamental way it affects the quality of human life, shaping it since birth.

The family is the basic socializing environment for life attitudes, social skills and individual personality. Family teaches the rules of living together in a group, and plays a role in the culture of the local community. Knowledge about the important role of the family in the life of individuals and society gained in the course of training by experts in various fields is essential for taking action in the service of man. Family members spend their time with relatives, accompanying them in a very difficult time of their life. In addition, the memory of the elderly family member is an important aspect of psychological motivation for further action.

Pope John Paul II addressed the following words to older people: "You have a mission to fulfill, you still have a lot to offer. According to the plan of God, every human being is a life that is constantly increasing, from the first spark of existence until the last breath." [53].

\section{References}

1. Bargiel-Marek Halina. Czy pogodna jesień musi być bezzębna. Gazeta Lekarska 2012; 9: 32.

2. Papieska Rada do Spraw Świeckich. Godność i posłannictwo ludzi starszych w Kościele i świecie. Watykan 1998. 
3. Ball S. Długowieczność mity i rzeczywistość. Wyd. Oficyna Wydawnicza Medyk, Warszawa 1996.

4. Synak B. Ludzie starzy w warunkach transformacji ustrojowej http://www.dps.pl/domy/index.php?rob=radar\&dzial $=12 \&$ art $=389 / 8 / 052013$.

5. Łukasik A, Barylski R, Irzmański R. Rehabilitacja osób $\mathrm{w}$ wieku podeszłym - terapia z wyboru dla starzejącego się społeczeństwa. Geriatria, Akademia Medycyny 2011; 5: 315 .

6. Chauchard P. Starzeć się we dwoje. Wyd. PAX, Warszawa 1998.

7. Żakowska-Wachełko B, Pudlich W. Pacjenci w starszym wieku. PZWL, Warsaw 1995.

8. Komisja Europejska. Wkład UE w propagowanie aktywnego starzenia się i solidarności między pokoleniami. Urząd Publikacji Unii Europejskiej, Luksemburg 2012.

9. Biercewicz M. Wielkie problemy geriatryczne. Pielęgniarka i Położna 2004; 10: 6-7.

10. Kędra E. Starość nie jest przestępstwem. Piel Zdr Pub 2011; 3: 209-15.

11. Żak M. Rehabilitacja w procesie leczenia osób starszych. Gerontol Pol 2008; 8: 12 .

12. Steuden S. Psychologia starzenia się i starości. PWN, Warsaw 2011.

13. Karczewski JK. Higiena Czelej, Lublin 2002.

14. Grabowska M. Źródła i przejawy we współczesnym świecie oraz metody przeciwdziałania. In: Kompendium pielęgnowania pacjentów w starszym wieku. Muszalik M, Kędziora- Kornatowska K (eds). Czelej, Lublin 2007; 4: 2.

15. Franek G. Ludzie w starszym wieku. Pielęgniarka i Położna 1997; 3: 7.

16. Abramowska Z. Seniorzy na nas liczą. Magazyn Pielęgniarki i Położnej 2010; 9: 8.

17. Schiefele J, Staund L, Dach MM. Pielęgniarstwo geriatryczne. Wydawnictwo Medyczne Urban \& Partner, Wrocław 1998.

18. Szarota Z. Starość zależna - opieka i pomoc społeczna. Perspektywa gerontologii społecznej. Krakowskie Towarzystwo Edukacyjne, Kraków 2011

19. Lucado M. Wieloryb nie może latać. O sztuce stawania się sobą, Wydawnictwo w drodze, Poznań 2009; 69-70 http:// teologia.blox.pl/2012/01/STARY-CZLOWIEK-I-ZYCIE-CIAGLE-PRZED-NIM.htm/ 28.05.2013.

20. Engster D. Rethinking care theory: the practice of caring and the obligation to care. Hypatia 2005; 20: 50-74.

21. Barth F. Grupy i granice etniczne: społeczna organizacja różnic kulturowych. In: Badanie kultury. Elementy teorii antropologicznej. Kontynuacje. Kempny M, Nowicka E (eds.). Wydawnictwo Naukowe PWN, Warsaw 2004.

22. Silvestein M, Gans D, Yang FM. Intergenerational support to aging parents: the role of norms and needs. Journal of Family Issues 2006; 27: 1068-104.

23. Finch J, Mason J. Negotiating family responsibilities. Routledge, London 1993.

24. Hochschild AR. Zarządzanie emocjami. Komercjalizacja ludzkich uczuć. PWN, Warsaw 2009.

25. Engster D. The heart of justice: care ethics and political theory. Oxford University Press, 2007.

26. Prusiński A. Praktyczne problemy neurologii w wieku podeszłym. ZAP, Lublin 2004.

27. Availabe at: http://wojciechlemanski.natemat.pl/49283,s tary-czlowiek-chce-juz-umrzec/ 052013.
28. Szatur-Jaworska B. Stan przestrzegania praw osób starszych w Polsce. Analiza i rekomendacje działan. Biuletyn Rzecznika Praw Obywatelskich, Warszawa 2008.

29. Papiernik J. http://www.rodzina.senior.pl/88,0,Opieka-nadstarszym-rodzicem-8211-kilka-porad-ekspertow, 10149.htm/ 062013.

30. Slany K, Małek A. Female emigration from Poland during the period of the systemic transformation (on the basis of the emigration from Poland to the USA and Italy). In: International migration: a multidimensional analysis. Slany K (ed.). Uczelniane Wydawnictwa Naukowo-Dydaktyczne AGH, Kraków 2005.

31. Slany K. Migracje kobiet. Perspektywa wielowymiarowa. Wydawnictwo Uniwersytetu Jagiellońskiego, Kraków 2008.

32. Biuletyn Migracyjny Polacy za granicą 2010; 27: $10 \mathrm{http} / / /$ sites.google.com/site/biulletynmigracyjny/archiwum-pdf [10.08.2011] /10.05.2013.

33. Wojtyńska A, Zielińska M. Polish migrants in Iceland facing the financial crisis. In: Gunnar Jóhannesson. Björnsdóttir H (ed.). Tjodarspegillinn: Rannsoknir i felagsvisindum XI, University of Iceland: Félagsvísindastofnun 2010 http://ug.academia.edu/Ma\%C5\%82gorzataZieli\%C5\% 84ska/Papers/527640/Polish_migrants_in_Iceland_facing_the_financial_crisis [26.01.2012].

34. Krzyżowski $€$, Mucha J. Odmiany nierówności AGH, Kraków. Polska Akademia Nauk Instytut Studiów Politycznych, Warszawa 2012

35. Stark Oded. The Migration of Labor, Basil Blackwell, Cambridge. Statistics Iceland, 2012, www.statice.is 1991/ 8.05.2013.

36. Twardowska-Rajewska J. Senior w domu. Opieka nad niepełnosprawnym seniorem. Wydawnictwo Naukowe UAM, Poznań 2007.

37. Tobiasz-Adamczyk R, Knurowski R, Brzyski P. Czy jeszcze ktoś pamięta o starości? In: Starość a process transformacji. Piątkowski W, Titkow A (eds.). Wydawnictwo UMCS, Lublin 2002

38. Rembowski J. Psychologiczne problemy starzenia się człowieka. PWN, Warsaw 1992.

39. Rosset E. Problemy ludzi starych w Polsce. PWE, Warsaw 1990.

40. Vaca KJ, Vaca BL, Daake CJ., et al. Review of nursing home regulations. Med Surg Nurs 2002; 7: 165-171.

41. Nolan M, Davies S. Integrating perspectives. In: Working with older people and their families. Nolan M, Davies S, Grant G. (eds.). Open University Press, Buckingham 2001; 160-178.

42. The Australian Congress of Nursing Council 2003.

43. Bauer M. Collaboration and control: nurses' constructions of the role of family in nursing home care. J Adv Nurs 2006; 1 : 45-52.

44. Commonwealth Department of Health an Aged Care 2001 Standards and Guidelines for Residential Aged Care Services Manual. Commonwealth Department of Health and Aged Care, Canberra. Retrieved from http://www.health.gov.au/manuals/sgr/sgrindex.htm on 22 November 2002/18.06.2012.

45. Commonwealth Department of Health and Aged Care 2002 Rights and Responsibilities of Residents of Aged Care Services. Commonwealth Department of Health and Aged Care, Canberra. Retrieved: http://www.health.gov. au/acc/publicat/qcoa/08info.htm 3 July 2003/18.06.2012.

46. The International Congress of Nurses Council 1998. 
47. Wild M. Instytut Badawczy Austriackiego Czerwonego Krzyża. Projekt - Przełamując tabu. Konferencja Katedry Epidemiologii i Medycyny Zapobiegawczej Collegium Medicum UJ 2009. Available at: http://www.epi.cm-uj. krakow.pl/23 052013.

48. Kuźmicz M. Pomoc i przemoc. Opieka jako proces zrozumienia. In: http://www.psychologia.edu.pl/czytelnia/ 131-przemoc/1461-pomoc-i-przemoc-opieka-jako-proceszrozumienia-maria-kuzmicz.htm/ 23.05.2013.

49. Zawada A. Starość jako wartość. Relacje międzypokoleniowe. Impuls, Krakow 2010.

50. Berezińcka W. Seniorzy i prognozy jak żyć długo i szczęśliwie. Magazyn Pielęgniarki i Położnej 2011; 12: 4.

51. Budzyńska-Kapczuk A. Nowe możliwości, nowe wyzwania. Pielęgniarka i Położna 2003; 12: 4.

52. Zboina B, Kulik T. Opieka pielęgniarska a jakość życia pacjentów. Problemy Pielęgniarstwa 2003; 1: 8-18.

53. Latasiewicz M, Sekściński A. Jan Paweł II. Rok po odejściu. Dom Wydawniczy Rafael, Krakow 2006.

\section{Address for correspondence:}

Grażyna Kowalik

os. Na Stoku 72/19

25-327 Kielce, Poland

Phone: +48 507186958

E-mail: grazynakowalik2@wp.pl 